\title{
A clean environmental week: let the nature breathe \\ Khaled Moustafa*
}

\section{Highlights:}

- About 36 billion tons of carbon dioxide (CO2) were produced in 2015 worldwide.

- Six countries emit CO2 more than all the rest.

- The biosphere could be seen as a living being that needs breaks to ingest pollutants.

- The cost of action to reduce pollution and $\mathrm{CO} 2$ emission today is less than the cost of inaction tomorrow.

- A 'clean environmental week' would allow reducing $\mathrm{CO} 2$ emission by about one billion ton a year.

\begin{abstract}
High levels of $\mathrm{CO}_{2}$ emissions in the atmosphere and toxic pollutants in air, water and food have serious repercussions on all life's systems, including living beings, environment and economy. Everyone on the Earth is concerned by pollution in some way or another, no matter where and how the pollution is produced as airborne and foodborne pollutants could circulate around the world in different ways, through for example climate components (wind, rain) and/or import and export of foodstuffs. Similarly to living beings that take advantage of day-night circadian rhythms to recover after diurnal hardships, the environment in its entirety could also be seen as a complex living system that needs regular breaks to assimilate or ingest toxic pollutants produced during intensive and continuous industrial activities. A global "Clean Environmental Week" is discussed as an attempt toward reducing air pollution and $\mathrm{CO}_{2}$ emissions through the interruption or the reduction of industrial polluting activities regularly for a week or so per year to let the nature 'breathe' or recover from environmentally challenging pollutions. If greenhouses gas emissions and pollution rates continue to increase at the same rates as they are today, uncontrollable serious climate effects might be inevitable and the air quality in some cities in the world might be hardly respirable in the future.
\end{abstract}

Keywords: air quality; alternate-day travels; carbon dioxide emission; clean environmental week, climate change; global warming; greenhouse gas emission; industrial pollution; no drive days; no work days; odd-even traffic restriction; pollution; renewable energy; traffic

\section{Increasingly 'carbonized' atmosphere}

Air pollution with greenhouse gases is a pervasive and chronic anthropogenic product of fossil fuel combustion, intensive vehicle traffic and unceasing industrial processes. Except for a 
handful of climate skeptics (most of whom are non-scientists) it is well admitted now that pollution and $\mathrm{CO}_{2}$ concentrations in the atmosphere in the few past centuries are virtually due to human economic activities and industrial processes (Solomon et al., 2007). Air pollutants and greenhouse gases emitted by human activities comprise mainly carbon dioxide $\left(\mathrm{CO}_{2}\right)$, methane $\left(\mathrm{CH}_{4}\right)$, nitrous oxide $\left(\mathrm{N}_{2} \mathrm{O}\right)$, chlorofluorocarbons and other macro- or micro-industrial products (commonly known as particulate matter $\leq 2.5 \mu \mathrm{m}$ in aerodynamic diameter $\left[\mathrm{PM}_{2.5}\right]$ ). According to the United States Environment Protection Agency (EPA), the carbon dioxide alone represents about $76 \%$ of the total greenhouse gases emitted by fossil fuel, industrial processes, forestry and other land use ${ }^{1}$. Methane in turn is about $16 \%$ and nitrous oxide is about $6 \%{ }^{1}$. The economic sectors that produce the most of greenhouses gases are: 1) electricity and heat production systems (25\%), 2) agriculture and other land use (24\%), 3) industry (21\%), 4) transportation (14\%), 5) other energy $(10 \%)^{1}$ and 6) cement industry (5\%) (Worrell et al., 2001). In 2015, the top carbon dioxide emitters were China (about $30 \%$ of the total $\mathrm{CO}_{2}$ emitted), the United States (15\%), India (7\%), Russia (5\%), and Japan (4\%) (Table 1.). The first five countries in the table (China, USA, India, Russia, Japan and Germany) produce altogether more than $60 \%$ of the global $\mathrm{CO}_{2}$ emitted from fossil fuel combustion and industrial processes. Between 1970 and 2015 , the production of $\mathrm{CO}_{2}$ has more than doubled, shifting from about 15 billion tons per year to more than 36 billion tons in 2015 (Figure 1). By 2050, the emission of greenhouse gasses will continue to increase by at least $50 \%$ due to a projected $70 \%$ growth in $\mathrm{CO}_{2}$ emissions from fossil energy uses (Marchal et al., 2011). Transport $\mathrm{CO}_{2}$ emissions are also projected to double owing to a strong increase in demand for cars in emerging countries (Marchal et al., 2011). Compared to the natural range of $\mathrm{CO}_{2}$ of about $180-300$ ppmv over the last 650,000 years (Solomon et al., 2007), the Earth's $\mathrm{CO}_{2}$ has already passed the threshold of 400 part per million by volume (ppmv) in 2016 (Kahn, 2016). As such, the Earth's atmosphere seems to be more increasingly saturated or 'carbonized' with $\mathrm{CO}_{2}$ emissions than it was in the past, which could lead to some unexpected climate consequences in the next decades if the emission level continues to rise without immediate and efficient actions to stabilize it.

\section{Effects of climate change and air pollution}

A large number of studies demonstrate that greenhouse gases and chronic exposures to air pollution could lead to serious effects on the environment, on the biome and on the entire human life from birth to the elderly. Increasing concentrations of $\mathrm{CO}_{2}$ are projected to induce climate change that in turn would affect all aspects of the biodiversity (Gitay et al., 2002). Due increasing pressures arising from human activities and natural processes, many of the current species are already under risk of extinction on the Earth (Gitay et al., 2002) and in the sea (Cheung et al., 2009). Some reports are more alarming than these by projecting the

\footnotetext{
${ }^{1}$ https://www.epa.gov/ghgemissions/global-greenhouse-gas-emissions-data
} 
consequences of anthropogenic climate change on biodiversity as a potential cause of underway sixth mass extinction episode (Rohr et al., 2008) (Bellard et al., 2012) (Pievani, 2014) (Ceballos et al., 2010) (Wake and Vredenburg, 2008) (Collins, 2010). At best, if $\mathrm{CO}_{2}$ emission continues to increase, it may contribute to uncontrollable and irreversible long-term climate change, such as dry-season rainfall reductions and inexorable sea level rise (Solomon et al., 2009). About $20 \%$ of coastal wetlands could also be lost due to sea-level rise as a consequence of potential climate change in the next decades (Gitay et al., 2002). In humans, elevated levels and/or long-term exposure to air pollutants can cause congenital anomalies and preterm births (Jacobs et al., 2016) (Gianicolo et al., 2014). Chronic air pollution is also associated with hypertension (Pitchika et al., 2017) (Liu et al., 2016) cardiovascular diseases (Burroughs Pena and Rollins, 2017) (Brook et al., 2010) and respiratory issues (Moustris et al., 2016) (Tsangari et al., 2016). Other reports associate air pollution to cancer such as lung cancer (Chen et al., 2016) (Kanwal et al., 2017) (Raaschou-Nielsen et al., 2013) (Bidoli et al., 2016) (Pope et al., 2002), pediatric cancer (Ortega-Garcia et al., 2017) (Lavigne et al., 2017), breast cancer (Gonzales et al., 2017) (Keramatinia et al., 2016), liver cancer (Pedersen et al., 2017), kidney cancer (Raaschou-Nielsen et al., 2017), gastric cancer (Chiu et al., 2011), and an elevated risk of cancer in various other digestive accessory organs (Wong et al., 2016). It was also reported that airborne particles induce important changes in the expression of pro-inflammatory cytokines and psoriatic skin disease-related genes, leading to potential dysfunction of the human epidermis (Kim et al., 2017). Chronic exposures to air pollutants would also increase DNA damages and cancer risks in traffic policemen (Tan et al., 2017) and would reduce life expectancy (Dziubanek et al., 2017) particularly among tuberculosis patients (Peng et al., 2017). Scaling down greenhouse emissions and improving air quality by reducing air pollutions could thus ameliorate the public health and save important medication costs while enhancing benefit-cost ratios (Simons et al., 2016) (Pascal et al., 2013) (Lu et al., 2016) (Gao et al., 2016).

\section{Potential actions on air pollution and $\mathrm{CO} 2$ emissions}

The climate system is currently close to enter, if not already entered, a zone of dangerous anthropogenic interference with potentially abrupt, irreversible and unmanageable consequences (Molina et al., 2009). To avoid such disasters, there is a paramount need for early, urgent and fast-action solutions (Molina et al., 2009). Taking early actions to tackle climate change issues has a number of advantages that could help reduce the risks of passing critical thresholds that trigger irreversible effects (Michaelowa and Rolfe, 2001). Environmentally engaged policies to reduce air pollution and $\mathrm{CO}_{2}$ emissions can take a multifaceted approach that could vary from simple actions, such as improving the design and efficiency of cooking devices, to more complex strategies in using alternative energy sources and reducing reliance on fossil energy to manufacturing new transportation means and constructing new eco-buildings. Climate-resilient and low emissions approaches could also be 
enhanced by other actions as simple as the establishment of walkways and cycling paths and encouraging the use of bikes to high-tech transportation means based on electric, hybrid or fully solar-energy sources. Good waste management and recycling systems (i.e., paper, plastic, and glass, etc.) and standardized manufacturing of all portable electric devices to always work with solar energy wherever and whenever available are also potential approaches to think of (Moustafa, 2016). As plants are the lungs of the earth, other actions to improve urban air quality and reduce air pollution and greenhouse gas emissions should include increasing the green surface planted by trees and shrubs (Nowak et al., 2006).

\section{Let the nature breathe for at least one week per year}

Emissions of air pollutants and greenhouse gases can also be reduced by cutting down the economic and industrial activities that lead to their production. In its entirety as a biological and integral ecosystem, the Earth's biosphere could be seen as a complex 'living being' that needs to recuperate after long exhausting industrial and polluting activities. Living organisms take advantages of day-night circadian rhythms to rest and recover from diurnal hardship events. In this context, the work rate of 24 hours per day and 7 days per week (24/7) might need rethinking. Is such a system economically and environmentally justified in regard with the endeavors to reduce $\mathrm{CO}_{2}$ emissions and its environmental consequences?

Similarly to living organisms, the environment could be treated as a living being in the sense that it needs time to 'ingest' its gas, solid and liquid pollutants. To reach such a goal and to allow natural ecosystems recover to some extent, anthropogenic polluting activities need to be slow down at least temporally or regularly to maintain a healthy and respirable atmosphere. Some countries already apply a driving restriction system (alternate-day travels or odd-even traffic restriction) at periods of urban pollution peaks to reduce urban exhaust gas emissions (Cai and Xie, 2011). However, such a policy has a little effect as it is applied for a short time and restricted to traffic and local levels only. In other words, the impact of alternate-day travel system is limited in time and space so that its effects on pollution are minor and transient. To produce more positive and more lasting impacts, global policies are required to stop or at least to decrease polluting industrial operations (i.e., those mentioned in table 1 that produce the most of $\mathrm{CO}_{2}$ emissions) for longer and regular periods of time at a worldwide level. For this, I propose a new concept of "Clean Environmental Week" to be observed and respected worldwide at the same calendar date of every year, independently of current cutoff days in each country. That is, a same week of the same month or, alternatively, a week at a rotating basis each month (for e.g., the first or last week of the respective months every year) could be defined as an international "Clean Environmental Week" in which major polluting industrial and traffic activities could be reduced to the bar minimum needed. As such, five days of no work week plus a weekend before and a weekend after will make a total of nine days of reducedpolluting activities that could have a tremendous and tangible impacts on the global 
environment. Concretely, the global emission of $\mathrm{CO}_{2}$ in 2015 was about 36 billion tons (table 1), which means that about one hundred million tons of $\mathrm{CO}_{2}$ was produced per day in 2015 (36 billion tons per year $=98,630,137$ tons per day). A period of 9-10 days of non-emission as suggested here, would thus save the production of $\mathrm{CO}_{2}$ by about 1 billion tons $(98,630,137 * 10=$ $986,301,370$ tons), which is roughly the equivalent to the amount of $\mathrm{CO}_{2}$ produced in an entire year some centuries ago, in $1890^{2}$ for instance.

To be as efficient as possible, the "Clean Environmental Week" needs to be respected worldwide and to include the interruption of most of the polluting industries (table 1 summarizes some of these), excluding the necessary and minimal vital functions of an economic system (for e.g., those to provide eating, drinking and urgent health cure materials, though the stock of many of such materials are usually manufactured in excess that could usually suffice for at least some weeks if not longer beyond the period suggested here as a 'clean environmental week'.

\section{How to set up the proposed approach?}

The approach could be set up simply by determining the culprit industrial operations in each country and then to stop them or to reduce them as if it was a prolonged weekend without major industrial activities. However, an important question could be raised here about the cultural and economic levels between industrialized and less industrialized countries; would it be fair to ask countries without heavy industry and countries relying on heavy industry make a total of nine days of reduced-polluting activities compared with those who pollute more and produce the most of $\mathrm{CO} 2$ emissions? And, how would we adjust these differences for clean environmental week to improve environmental health and minimize economic impact? To answer these questions, we need to bear in mind that the overproduction of $\mathrm{CO}_{2}$ is now a fact that makes all people concerned regardless of the industrial level of each country because a global climate change would not stop on custom services or pass through administrative borders. Rather, it would affect all of us, poor or rich, northern or southern, eastern or western with opposed or mixed changes (i.e., extreme drought here and severe floods elsewhere, harsh cold in somewhere and suffocating heat elsewhere and so on). Of course, there should be more responsibility and efforts to reduce $\mathrm{CO}_{2}$ rates on major $\mathrm{CO}_{2}$ emitters than on small ones, proportionally to each contribution in $\mathrm{CO}_{2}$ emission, but a climate change would likely induce global consequences that can affect the entire world. The responsibility should ideally be proportional to the contribution in $\mathrm{CO} 2$ emission but there is a risk that asking only countries with heavy $\mathrm{CO} 2$ emissions to reduce their emissions might lead them to relocate some of their polluting industries to other countries with less restriction to escape the limit regulation. This is currently the case for many industrial processes that have been relocated to China (where the production costs are relatively cheap compared with other countries), making China as a major

\footnotetext{
${ }^{2}$ http://www.wri.org/blog/2014/05/history-carbon-dioxide-emissions
} 
CO2 emitter (table 1) because a lot of industries have been relocated there. So, reducing the emission in one country and increasing it in another would not solve the problem.

In all cases, a potential clean environmental week is not incompatible with other engagements or actions signed or taken during the United Nations series of conferences on climate change and environmental programs (e.g., Conference of the parties; COP) but as a possible complimentary and global action to consider for producing the most positive impact achievable alongside with other procedures in the same direction. As inferred above, about ten days of simple environmentally clean week would cut off about 1 billion tons of $\mathrm{CO}_{2}$ per year, suggesting the potential importance of such a measure. Ideally and logically, the countries that produce more $\mathrm{CO}_{2}$ should incur more responsibility and, why not, economic sanctions in case of non-compliance with the obligations and agreements to reduce $\mathrm{CO}_{2}$ emissions and other pollutants. A global environmental week applied worldwide would sensitize more people on the importance of climate change and encourage them to participate in mitigating it, each with the means at hand.

However, a "clean" environmental week should not be seen as a "vacation week" to induce traffic congestion on holiday roads, but as a cleaning and curing environmental week to enhance nature recuperation from global pollution. During such a "no-work" week, the emission of toxic pollutants and dangerous gases such as carbon monoxide, sulfur dioxide, nitrogen oxides, methane, and chemical vapors released from polluting industries, motor vehicle exhaust and factories should be reduced to the bare minimum. The perception of pollution risks associated with such pollutions in some European countries makes many people ready to pay to avoid pollution-related health risks (Istamto et al., 2014). The long-term benefits on environment and health of reduced industrial and polluting activities during a week or so would outweigh minor short-term losses that might be associated with slowed economic activities during that week. The international Organization for Economic Co-operation and Development (OECD) compared the cost of actions/inactions on climate change and it projects that the cost of maintaining the $2{ }^{\circ} \mathrm{C}$ goal would reduce the growth of global GDP (Growth Domestic Product) from only 3.5 to $3.3 \%$ per year (or by 0.2 percentage points) on average, costing roughly $5.5 \%$ of global GDP in 2050 (OECD, 2012). When this cost is compared with the potential cost of inaction that could be as high as $14 \%$ of average world consumption per capita, it appears that delaying action is extremely costly (OECD, 2012). Moderate or delayed action up to 2020 (such as implementing the Copenhagen/Cancun agreements only, or waiting for better technologies to come on stream) would imply 50\% higher costs in 2050 compared to timely action, and potentially entail higher environmental risks (OECD, 2012). As such, to reduce the risk of potential catastrophic climate change, we should act now to slow down and reverse the trend of $\mathrm{CO} 2$ emission and pollutant release in the atmosphere to stabilize their concentrations within the natural ranges to limit global warming. Whatever the cost of actions 
today, it would be much less than the cost of inaction tomorrow, both from economic and human perspective.

A global and momentous problem needs global and momentous policies. A universal "Clean Environmental Week" can be one of those actions that could potentially be considered among other actions to slow down pollution and reduce $\mathrm{CO}_{2}$ emissions at least in part to improve environmental healthiness, mitigate global warming and avoid future worst-case scenarios in health and environmental management systems.

\section{Disclosure: None.}

\section{References}

Bellard C, Bertelsmeier C, Leadley P, Thuiller W, Courchamp F. Impacts of climate change on the future of biodiversity. Ecol Lett 2012; 15: 365-77.

Bidoli E, Pappagallo M, Birri S, Frova L, Zanier L, Serraino D. Residential Proximity to Major Roadways and Lung Cancer Mortality. Italy, 1990-2010: An Observational Study. Int J Environ Res Public Health 2016; 13: 191.

Brook RD, Rajagopalan S, Pope CA, Brook JR, Bhatnagar A, Diez-Roux AV, et al. Particulate matter air pollution and cardiovascular disease. Circulation 2010; 121: 2331-2378.

Burroughs Pena MS, Rollins A. Environmental Exposures and Cardiovascular Disease: A Challenge for Health and Development in Low- and Middle-Income Countries. Cardiol Clin 2017; 35: 71-86.

Cai H, Xie S. Traffic-related air pollution modeling during the 2008 Beijing Olympic Games: the effects of an odd-even day traffic restriction scheme. Sci Total Environ 2011; 409: 1935-48.

Ceballos G, García A, Ehrlich PR. The sixth extinction crisis: loss of animal populations and species. Journal of Cosmology 2010; 8: 31.

Chen X, Zhang LW, Huang JJ, Song FJ, Zhang LP, Qian ZM, et al. Long-term exposure to urban air pollution and lung cancer mortality: A 12-year cohort study in Northern China. Sci Total Environ 2016; 571: 855-61.

Cheung WWL, Lam VWY, Sarmiento JL, Kearney K, Watson R, Pauly D. Projecting global marine biodiversity impacts under climate change scenarios. Fish and Fisheries 2009; 10: 235-251.

Chiu HF, Tsai SS, Chen PS, Liao YH, Liou SH, Wu TN, et al. Traffic air pollution and risk of death from gastric cancer in Taiwan: petrol station density as an indicator of air pollutant exposure. J Toxicol Environ Health A 2011; 74: 1215-24.

Collins JP. Amphibian decline and extinction: what we know and what we need to learn. Dis Aquat Organ 2010; 92: 93-9.

Dziubanek G, Spychała A, Marchwińska-Wyrwał E, Rusin M, Hajok I, Ćwieląg-Drabek M, et al. Long-term exposure to urban air pollution and the relationship with life expectancy in cohort of 3.5 million people in Silesia. Science of The Total Environment 2017; 580: 1-8.

Gao J, Yuan Z, Liu X, Xia X, Huang X, Dong Z. Improving air pollution control policy in China-A perspective based on cost-benefit analysis. Science of The Total Environment 2016; 543, Part A: 307-314.

Gianicolo EAL, Mangia C, Cervino M, Bruni A, Andreassi MG, Latini G. Congenital anomalies among live births in a high environmental risk area-A case-control study in Brindisi (southern Italy). Environmental research 2014; 128: 9-14.

Gitay H, Suárez A, Watson RT, Dokken DJ. Climate change and biodiversity. IPCC Technical Paper V 2002. 
Gonzales MC, Yu P, Shiao SP. MTHFR Gene Polymorphism-Mutations and Air Pollution as Risk Factors for Breast Cancer: A Metaprediction Study. Nurs Res 2017; 66: 152-163.

Istamto $T$, Houthuijs $D$, Lebret $E$. Willingness to pay to avoid health risks from road-traffic-related air pollution and noise across five countries. Sci Total Environ 2014; 497-498: 420-9.

Jacobs M, Zhang G, Chen S, Mullins B, Bell M, Jin L, et al. The association between ambient air pollution and selected adverse pregnancy outcomes in China: A systematic review. Science of The Total Environment 2016.

Kahn B. The World Passes 400 PPM Threshold. Permanently. Climate Central, 2016.

Kanwal M, Ding XJ, Cao Y. Familial risk for lung cancer. Oncol Lett 2017; 13: 535-542.

Keramatinia A, Hassanipour S, Nazarzadeh M, Wurtz M, Monfared AB, Khayyamzadeh M, et al. Correlation Between Nitrogen Dioxide as an Air Pollution Indicator and Breast Cancer: a Systematic Review and Meta- Analysis. Asian Pac J Cancer Prev 2016; 17: 419-24.

Kim HJ, Bae IH, Son ED, Park J, Cha N, Na HW, et al. Transcriptome analysis of airborne PM2.5-induced detrimental effects on human keratinocytes. Toxicol Lett 2017; 273: 26-35.

Lavigne E, Belair MA, Do MT, Stieb DM, Hystad P, van Donkelaar A, et al. Maternal exposure to ambient air pollution and risk of early childhood cancers: A population-based study in Ontario, Canada. Environ Int 2017; 100: 139-147.

Liu W-T, Lee K-Y, Lee H-C, Chuang H-C, Wu D, Juang J-N, et al. The association of annual air pollution exposure with blood pressure among patients with sleep-disordered breathing. Science of The Total Environment 2016; 543, Part A: 61-66.

Lu X, Yao T, Fung JC, Lin C. Estimation of health and economic costs of air pollution over the Pearl River Delta region in China. Sci Total Environ 2016; 566-567: 134-43.

Marchal V, Dellink R, Van Vuuren D, Clapp C, Chateau J, Magné B, et al. OECD Environmental Outlook to 2050. Organization for Economic Co-operation and Development (OECD), 2011.

Michaelowa A, Rolfe C. Early action to reduce greenhouse gas emissions before the commitment period of the Kyoto protocol: advantages and disadvantages. Environ Manage 2001; 28: 281-92.

Molina M, Zaelke D, Sarma KM, Andersen SO, Ramanathan V, Kaniaru D. Reducing abrupt climate change risk using the Montreal Protocol and other regulatory actions to complement cuts in CO2 emissions. Proc Natl Acad Sci U S A 2009; 106: 20616-21.

Moustafa K. Food and Sustainability Challenges Under Climate Changes. Sci Eng Ethics 2016; 22: 18311836.

Moustris KP, Proias GT, Larissi IK, Nastos PT, Koukouletsos KV, Paliatsos AG. Health impacts due to particulate air pollution in Volos City, Greece. J Environ Sci Health A Tox Hazard Subst Environ Eng 2016; 51: 15-20.

Nowak DJ, Crane DE, Stevens JC. Air pollution removal by urban trees and shrubs in the United States. Urban Forestry \& Urban Greening 2006; 4: 115-123.

OECD. OECD Environmental Outlook to 2050: The Consequences of Inaction. Paris: OECD Publishing, 2012.

Ortega-Garcia JA, Lopez-Hernandez FA, Carceles-Alvarez A, Fuster-Soler JL, Sotomayor DI, Ramis R. Childhood cancer in small geographical areas and proximity to air-polluting industries. Environ Res 2017; 156: 63-73.

Pascal M, Corso M, Chanel O, Declercq C, Badaloni C, Cesaroni G, et al. Assessing the public health impacts of urban air pollution in 25 European cities: results of the Aphekom project. Science of the Total Environment 2013; 449: 390-400.

Pedersen M, Andersen ZJ, Stafoggia M, Weinmayr G, Galassi C, Sorensen M, et al. Ambient air pollution and primary liver cancer incidence in four European cohorts within the ESCAPE project. Environ Res 2017; 154: 226-233. 
Peng Z, Liu C, Xu B, Kan H, Wang W. Long-term exposure to ambient air pollution and mortality in a Chinese tuberculosis cohort. Sci Total Environ 2017; 580: 1483-1488.

Pievani T. The sixth mass extinction: Anthropocene and the human impact on biodiversity. Rendiconti Lincei 2014; 25: 85-93.

Pitchika A, Hampel R, Wolf K, Kraus U, Cyrys J, Babisch W, et al. Long-term associations of modeled and self-reported measures of exposure to air pollution and noise at residence on prevalent hypertension and blood pressure. Science of The Total Environment 2017; 593-594: 337-346.

Pope CA, 3rd, Burnett RT, Thun MJ, Calle EE, Krewski D, Ito K, et al. Lung cancer, cardiopulmonary mortality, and long-term exposure to fine particulate air pollution. JAMA 2002; 287: 1132-41.

Raaschou-Nielsen O, Andersen ZJ, Beelen R, Samoli E, Stafoggia M, Weinmayr G, et al. Air pollution and lung cancer incidence in 17 European cohorts: prospective analyses from the European Study of Cohorts for Air Pollution Effects (ESCAPE). Lancet Oncol 2013; 14: 813-22.

Raaschou-Nielsen O, Pedersen M, Stafoggia M, Weinmayr G, Andersen ZJ, Galassi C, et al. Outdoor air pollution and risk for kidney parenchyma cancer in 14 European cohorts. Int J Cancer 2017; 140: 1528-1537.

Rohr JR, Raffel TR, Romansic JM, McCallum H, Hudson PJ. Evaluating the links between climate, disease spread, and amphibian declines. Proc Natl Acad Sci U S A 2008; 105: 17436-41.

Simons K, Devos S, Putman K, Coomans D, Van Nieuwenhuyse A, Buyl R. Direct cost saving potential in medication costs due to a reduction in outdoor air pollution for the Brussels Capital Region. Science of The Total Environment 2016; 562: 760-765.

Solomon S, Plattner G-K, Knutti R, Friedlingstein P. Irreversible climate change due to carbon dioxide emissions. Proceedings of the national academy of sciences 2009: pnas. 0812721106.

Solomon S, Qin D, Manning M, Chen Z, Marquis M, Averyt K, et al. Climate Change 2007 - The Physical Science Basis: Working group I Contribution to the Fourth Assessment Report of the Intergovernmental Panel on Climate Change (IPCC). Vol 4: Cambridge University Press, Cambridge, United Kingdom and New York, NY, USA., 2007.

Tan C, Lu S, Wang Y, Zhu Y, Shi T, Lin M, et al. Long-term exposure to high air pollution induces cumulative DNA damages in traffic policemen. Sci Total Environ 2017; 593-594: 330-336.

Tsangari H, Paschalidou AK, Kassomenos AP, Vardoulakis S, Heaviside C, Georgiou KE, et al. Extreme weather and air pollution effects on cardiovascular and respiratory hospital admissions in Cyprus. Science of The Total Environment 2016; 542, Part A: 247-253.

Wake DB, Vredenburg VT. Are we in the midst of the sixth mass extinction? A view from the world of amphibians. Proceedings of the National Academy of Sciences 2008; 105: 11466-11473.

Wong CM, Tsang H, Lai HK, Thomas GN, Lam KB, Chan KP, et al. Cancer Mortality Risks from Long-term Exposure to Ambient Fine Particle. Cancer Epidemiol Biomarkers Prev 2016; 25: 839-45.

Worrell E, Price L, Martin N, Hendriks C, Meida LO. Carbon dioxide emissions from the global cement industry 1. Annual Review of Energy and the Environment 2001; 26: 303-329. 
Table 1. " $\mathrm{CO}_{2}$ emissions of fossil fuel use and industrial processes (cement production, carbonate use of limestone and dolomite, non-energy use of fuels and other combustions, chemical and metal processes, solvents, agricultural liming and urea, waste and fossil fuel fires). Excluded are: short-cycle biomass burning (such as agricultural waste burning), large-scale biomass burning (such as forest fires) and carbon emissions/removals of land-use, land-use change and forestry"*.

\begin{tabular}{|c|c|c|c|c|c|c|c|c|c|c|c|}
\hline & & & & Global CC & emission $p$ & year per $c$ & ntry (Ktons & & & & \\
\hline Country & 2006 & 2007 & 2008 & 2009 & 2010 & 2011 & 2012 & 2013 & 2014 & 2015 & $\begin{array}{l}\text { Percent of } \\
\text { CO2 emitted } \\
\text { in } 2015\end{array}$ \\
\hline China** & 6870759 & 7515037 & 7699949 & 8246582 & 8986614 & 9844525 & 10056756 & 10503137 & 10711037 & 10641789 & 29.50996 \\
\hline USA** & 5765135 & 5847966 & 5659277 & 5243236 & 5519484 & 5391417 & 5164192 & 5255530 & 5312226 & 5172338 & 14.34303 \\
\hline India** & 1367406 & 1439192 & 1536650 & 1738106 & 1848710 & 1961663 & 2090857 & 2191277 & 2334381 & 2454968 & 6.80769 \\
\hline Russia** & 1764650 & 1766346 & 1743343 & 1652898 & 1735583 & 1820098 & 1833976 & 1824579 & 1822210 & 1760895 & 4.88301 \\
\hline Japan** & 1289035 & 1310630 & 1226781 & 1163613 & 1219095 & 1258289 & 1293511 & 1312750 & 1281569 & 1252890 & 3.47430 \\
\hline Germany** & 844435 & 817319 & 828292 & 768284 & 811861 & 793891 & 801677 & 815812 & 773020 & 777905 & 2.15715 \\
\hline Iran & 500311 & 534178 & 544451 & 565166 & 568920 & 578502 & 591310 & 600055 & 625021 & 633750 & 1.75740 \\
\hline South Korea & 530686 & 535783 & 546589 & 556099 & 600870 & 617612 & 614771 & 611531 & 611741 & 617285 & 1.71175 \\
\hline Canada & 545677 & 570974 & 563980 & 532609 & 545088 & 551261 & 556797 & 568364 & 572262 & 555401 & 1.54014 \\
\hline Saudi Arabia & 321190 & 338145 & 363299 & 390882 & 420058 & 438213 & 455673 & 459502 & 486767 & 505565 & 1.40195 \\
\hline Indonesia & 383593 & 398802 & 396354 & 411644 & 423416 & 433103 & 443625 & 452744 & 483633 & 502961 & 1.39472 \\
\hline Brazil & 363134 & 379565 & 399717 & 373531 & 423798 & 442313 & 457077 & 485620 & 505395 & 486229 & 1.34833 \\
\hline Mexico & 425604 & 440779 & 437759 & 434049 & 445291 & 460511 & 481703 & 486432 & 480692 & 472018 & 1.30892 \\
\hline Australia & 407286 & 427487 & 430374 & 435530 & 420677 & 428610 & 428229 & 429079 & 438504 & 446348 & 1.23774 \\
\hline South Africa & 409496 & 429678 & 453072 & 426752 & 433086 & 414565 & 410065 & 423218 & 431469 & 417161 & 1.15680 \\
\hline United Kingdom & 555854 & 546532 & 533279 & 478784 & 493734 & 455843 & 467584 & 455878 & 415177 & 398524 & 1.10512 \\
\hline Turkey & 275440 & 300130 & 303359 & 297693 & 307985 & 328282 & 339238 & 324736 & 352593 & 357157 & 0.99041 \\
\hline Italy & 489493 & 482151 & 466539 & 413512 & 422825 & 412039 & 395145 & 362512 & 335610 & 352886 & 0.97856 \\
\hline France & 399752 & 394216 & 391486 & 370957 & 380777 & 352560 & 351479 & 355664 & 323495 & 327787 & 0.90896 \\
\hline Poland & 322674 & 324151 & 319010 & 304068 & 324465 & 319354 & 309560 & 304238 & 289144 & 294879 & 0.81771 \\
\hline Thailand & 228576 & 234029 & 236316 & 229451 & 243361 & 249874 & 258478 & 268589 & 277664 & 279253 & 0.77438 \\
\hline Taiwan & 279710 & 282292 & 270256 & 256235 & 273033 & 272157 & 274256 & 277397 & 280987 & 279174 & 0.77416 \\
\hline Kazakhstan & 216166 & 225573 & 259843 & 232848 & 249093 & 269958 & 256771 & 267585 & 274067 & 267978 & 0.74311 \\
\hline Spain & 356423 & 370293 & 338163 & 298370 & 284604 & 286096 & 276360 & 250801 & 245637 & 262683 & 0.72843 \\
\hline Malaysia & 183252 & 200817 & 213613 & 192125 & 205448 & 212224 & 215643 & 232041 & 235668 & 245371 & 0.68042 \\
\hline Ukraine & 367116 & 378228 & 358243 & 297733 & 320148 & 336311 & 326701 & 316849 & 274682 & 228688 & 0.63416 \\
\hline Egypt & 180715 & 192951 & 198847 & 204072 & 210109 & 221507 & 228318 & 219686 & 222551 & 226985 & 0.62944 \\
\hline Viet Nam & 101950 & 112782 & 124584 & 140823 & 154589 & 161729 & 165021 & 169176 & 187942 & 206028 & 0.57132 \\
\hline United Arab Emirates & 125920 & 136352 & 158731 & 163605 & 170972 & 176736 & 187450 & 190141 & 190540 & 199253 & 0.55253 \\
\hline Argentina & 169468 & 176467 & 189628 & 181170 & 187466 & 192018 & 191557 & 188068 & 189189 & 191199 & 0.53020 \\
\hline Venezuela & 165856 & 150156 & 184624 & 184084 & 197246 & 176173 & 196460 & 185748 & 183400 & 178568 & 0.49517 \\
\hline Pakistan & 143627 & 159407 & 155820 & 158387 & 154325 & 154691 & 153809 & 156045 & 165985 & 174843 & 0.48485 \\
\hline Netherlands & 174300 & 175962 & 178854 & 172314 & 183239 & 171874 & 170902 & 169529 & 160706 & 165317 & 0.45843 \\
\hline
\end{tabular}




\begin{tabular}{|c|c|c|c|c|c|c|c|c|c|c|c|}
\hline Iraq & 73198 & 79652 & 90416 & 107856 & 121820 & 129930 & 140741 & 153829 & 158010 & 160623 & 0.44541 \\
\hline Algeria & 101399 & 104251 & 108779 & 112547 & 114750 & 120271 & 128343 & 131435 & 141615 & 147692 & 0.40955 \\
\hline Philippines & 73399 & 77285 & 79126 & 79908 & 85914 & 86841 & 87559 & 97034 & 103666 & 113035 & 0.31345 \\
\hline Czech Republic & 129494 & 130658 & 125599 & 116798 & 121353 & 119867 & 117827 & 113429 & 110923 & 111092 & 0.30806 \\
\hline Uzbekistan & 118897 & 119417 & 119137 & 107737 & 106254 & 114548 & 115947 & 104189 & 107752 & 109845 & 0.30460 \\
\hline Belgium & 114716 & 111277 & 114779 & 104786 & 111211 & 102672 & 98124 & 98363 & 93733 & 97002 & 0.26899 \\
\hline Kuwait & 76763 & 76636 & 80652 & 86955 & 86836 & 90310 & 92098 & 91235 & 91818 & 95013 & 0.26347 \\
\hline Turkmenistan & 54360 & 60169 & 63274 & 54895 & 61710 & 67220 & 69720 & 70893 & 80553 & 94236 & 0.26132 \\
\hline Qatar & 47789 & 54562 & 59731 & 63930 & 71805 & 76264 & 83164 & 85811 & 84471 & 88825 & 0.24631 \\
\hline Nigeria & 81550 & 75553 & 78074 & 72174 & 80468 & 87683 & 81596 & 80467 & 81768 & 86896 & 0.24096 \\
\hline Romania & 108929 & 106484 & 104502 & 85279 & 82238 & 88909 & 89796 & 78715 & 79264 & 81247 & 0.22530 \\
\hline Chile & 61386 & 69783 & 72827 & 69135 & 73590 & 80151 & 78538 & 83115 & 81492 & 81110 & 0.22492 \\
\hline Colombia & 59420 & 61108 & 61642 & 65034 & 64377 & 71659 & 69906 & 72600 & 77044 & 80967 & 0.22453 \\
\hline Oman & 42298 & 46338 & 52761 & 60425 & 64665 & 71677 & 72829 & 75202 & 74855 & 78446 & 0.21753 \\
\hline Austria & 78632 & 76434 & 77140 & 69551 & 75992 & 75495 & 74638 & 74540 & 71626 & 74244 & 0.20588 \\
\hline Bangladesh & 40982 & 44676 & 50639 & 55070 & 60356 & 60559 & 61732 & 64445 & 67039 & 71360 & 0.19788 \\
\hline Greece & 102575 & 106202 & 102121 & 96235 & 89188 & 86109 & 83454 & 74927 & 71095 & 68292 & 0.18938 \\
\hline Israel & 65167 & 67550 & 67916 & 67102 & 70421 & 69827 & 70929 & 64889 & 63035 & 65716 & 0.18223 \\
\hline Belarus & 67605 & 64248 & 67238 & 64890 & 69641 & 65534 & 66478 & 66654 & 68016 & 64800 & 0.17969 \\
\hline Serbia \& Montenegro & 63194 & 61505 & 61222 & 57055 & 58261 & 62862 & 61931 & 62856 & 59974 & 63374 & 0.17574 \\
\hline North Korea & 80841 & 67595 & 74584 & 72771 & 68836 & 56646 & 56973 & 58004 & 61344 & 62995 & 0.17469 \\
\hline Morocco & 46269 & 47965 & 48631 & 48444 & 51172 & 54731 & 55583 & 54636 & 58392 & 59246 & 0.16429 \\
\hline Bulgaria & 53143 & 57078 & 53940 & 45887 & 48473 & 53631 & 53305 & 47707 & 50799 & 53432 & 0.14817 \\
\hline Peru & 31255 & 34179 & 38723 & 41618 & 44939 & 47985 & 48000 & 49701 & 51140 & 52572 & 0.14578 \\
\hline Libya & 54711 & 52373 & 53735 & 61075 & 63877 & 41654 & 53183 & 52400 & 50067 & 52153 & 0.14462 \\
\hline Portugal & 61123 & 60622 & 57933 & 57753 & 52027 & 51622 & 49107 & 47732 & 47283 & 50792 & 0.14085 \\
\hline Singapore & 41769 & 43390 & 44036 & 42191 & 45444 & 44715 & 44651 & 45136 & 46786 & 48531 & 0.13458 \\
\hline Finland & 72096 & 69527 & 61352 & 58903 & 67310 & 59517 & 57948 & 58477 & 53728 & 48505 & 0.13451 \\
\hline Hungary & 59834 & 58243 & 57168 & 50900 & 51804 & 50044 & 49084 & 46350 & 45866 & 48186 & 0.13362 \\
\hline Syrian Arab Republic & 61325 & 64581 & 65943 & 61645 & 61451 & 56357 & 52435 & 44649 & 44902 & 45898 & 0.12728 \\
\hline Hong Kong & 42551 & 45583 & 44572 & 47753 & 42418 & 47367 & 47416 & 48413 & 49261 & 45703 & 0.12674 \\
\hline Norway & 43956 & 44743 & 44596 & 43720 & 45963 & 44925 & 43574 & 43765 & 43048 & 43109 & 0.11954 \\
\hline Sweden & 56722 & 53388 & 51364 & 47063 & 53223 & 47738 & 46101 & 44463 & 43671 & 42496 & 0.11784 \\
\hline Ecuador & 29118 & 30985 & 30883 & 34506 & 36226 & 37913 & 37984 & 40834 & 42498 & 41749 & 0.11577 \\
\hline Switzerland & 47190 & 45219 & 46743 & 45209 & 46924 & 42833 & 42910 & 43550 & 39394 & 40283 & 0.11171 \\
\hline Denmark & 58761 & 53985 & 50730 & 48492 & 48216 & 43081 & 41748 & 43645 & 40238 & 36908 & 0.10235 \\
\hline Ireland & 48863 & 47671 & 46992 & 41850 & 41717 & 36962 & 36364 & 35409 & 34882 & 36635 & 0.10159 \\
\hline Slovakia & 42793 & 41605 & 42008 & 37772 & 40088 & 37900 & 37833 & 38212 & 35415 & 36254 & 0.10053 \\
\hline Trinidad \& Tobago & 34545 & 37722 & 37006 & 35342 & 38654 & 36531 & 34080 & 35446 & 35533 & 35283 & 0.09784 \\
\hline Cuba & 26525 & 27446 & 25951 & 33314 & 30692 & 29305 & 29841 & 32871 & 33753 & 34459 & 0.09555 \\
\hline New Zealand & 36762 & 35977 & 36869 & 33941 & 33900 & 33261 & 33664 & 33124 & 33739 & 33660 & 0.09334 \\
\hline
\end{tabular}




\begin{tabular}{|c|c|c|c|c|c|c|c|c|c|c|c|}
\hline Azerbaijan & 30683 & 27880 & 30713 & 25699 & 24534 & 27785 & 29291 & 30320 & 31706 & 32727 & 0.09075 \\
\hline Yemen & 22292 & 24792 & 24897 & 27047 & 27042 & 22499 & 22655 & 29990 & 30440 & 30679 & 0.08507 \\
\hline Tunisia & 23966 & 24716 & 25155 & 24835 & 25600 & 24270 & 25229 & 25296 & 27255 & 29506 & 0.08182 \\
\hline Estonia & 16080 & 20637 & 19086 & 15510 & 18541 & 20230 & 27132 & 29255 & 28099 & 29252 & 0.08112 \\
\hline $\begin{array}{l}\text { Bosnia \& } \\
\text { Herzegovina }\end{array}$ & 18896 & 19912 & 21820 & 21857 & 22539 & 25419 & 24880 & 24757 & 23516 & 24637 & 0.06832 \\
\hline Dominican Republic & 21062 & 21081 & 21903 & 20273 & 20673 & 22250 & 22891 & 22633 & 23860 & 24273 & 0.06731 \\
\hline Angola & 15759 & 16376 & 18637 & 20483 & 23221 & 23212 & 22184 & 22012 & 22497 & 23025 & 0.06385 \\
\hline Jordan & 20223 & 21105 & 20665 & 21175 & 20658 & 21157 & 21891 & 21991 & 22696 & 22929 & 0.06358 \\
\hline Bahrain & 16166 & 18890 & 18239 & 18686 & 19075 & 19686 & 19743 & 21433 & 21003 & 22146 & 0.06141 \\
\hline Lebanon & 15557 & 14132 & 17732 & 21486 & 20543 & 20880 & 21084 & 20986 & 21435 & 21562 & 0.05979 \\
\hline Croatia & 22888 & 24599 & 23279 & 21673 & 20735 & 20623 & 20354 & 20151 & 20226 & 20538 & 0.05695 \\
\hline Bolivia & 11098 & 12040 & 13106 & 13834 & 15141 & 16406 & 16930 & 17109 & 17849 & 18123 & 0.05025 \\
\hline Sudan (former) & 12790 & 13969 & 14773 & 15331 & 16102 & 16694 & 16401 & 16447 & 16422 & 16808 & 0.04661 \\
\hline Mongolia & 10992 & 11561 & 11700 & 12159 & 13089 & 13566 & 14082 & 15055 & 16060 & 16438 & 0.04558 \\
\hline Slovenia & 18075 & 18004 & 18941 & 17098 & 16138 & 16111 & 15994 & 15511 & 15178 & 15610 & 0.04329 \\
\hline Kenya & 9864 & 9865 & 10408 & 12203 & 13233 & 13548 & 13123 & 14444 & 14869 & 15201 & 0.04215 \\
\hline Ghana & 8607 & 8953 & 8078 & 9799 & 11298 & 12447 & 13512 & 14436 & 14487 & 14916 & 0.04136 \\
\hline Sri Lanka & 12970 & 14214 & 13524 & 13225 & 14459 & 15330 & 15554 & 13717 & 14495 & 14704 & 0.04077 \\
\hline Guatemala & 11880 & 12639 & 11427 & 12036 & 11774 & 11731 & 11899 & 13550 & 14234 & 14538 & 0.04031 \\
\hline Zimbabwe & 10875 & 10527 & 8032 & 8727 & 9673 & 10568 & 10889 & 11427 & 13973 & 13692 & 0.03797 \\
\hline Lithuania & 13957 & 15070 & 14991 & 12616 & 13425 & 13516 & 13833 & 12752 & 12478 & 12478 & 0.03460 \\
\hline Myanmar & 10162 & 10633 & 8094 & 7595 & 8356 & 8504 & 9011 & 10419 & 11262 & 11640 & 0.03228 \\
\hline Cameroon & 8717 & 9695 & 10024 & 10612 & 10069 & 9879 & 10007 & 10682 & 10858 & 11117 & 0.03083 \\
\hline Tanzania & 5983 & 5836 & 6128 & 5868 & 6402 & 7617 & 8800 & 9852 & 10278 & 10778 & 0.02989 \\
\hline Panama & 7552 & 7285 & 7368 & 8495 & 9061 & 9571 & 10288 & 9752 & 10056 & 10263 & 0.02846 \\
\hline Luxembourg & 11874 & 11277 & 11163 & 10538 & 11147 & 11017 & 10636 & 10034 & 10097 & 10235 & 0.02838 \\
\hline Côte d Ivoire & 6328 & 6196 & 6932 & 6553 & 7223 & 7028 & 7910 & 8687 & 9201 & 9889 & 0.02742 \\
\hline Ethiopia & 5667 & 6164 & 6616 & 6619 & 6290 & 6864 & 7810 & 9365 & 9671 & 9885 & 0.02741 \\
\hline Macedonia & 9648 & 10328 & 10118 & 9093 & 9130 & 10132 & 9820 & 9841 & 9607 & 9787 & 0.02714 \\
\hline Jamaica & 12297 & 12212 & 11745 & 8276 & 7904 & 8337 & 8266 & 8776 & 9012 & 9180 & 0.02546 \\
\hline Honduras & 7169 & 8857 & 8574 & 8102 & 8001 & 8241 & 8527 & 8607 & 8887 & 9081 & 0.02518 \\
\hline Afghanistan & 3245 & 2902 & 3958 & 5055 & 6316 & 6952 & 7482 & 8021 & 8542 & 8663 & 0.02402 \\
\hline Costa Rica & 6825 & 7624 & 7553 & 7278 & 7212 & 7439 & 7561 & 7875 & 8099 & 8285 & 0.02297 \\
\hline Brunei Darussalam & 7644 & 7246 & 7949 & 7934 & 7289 & 7463 & 7127 & 7079 & 7777 & 8257 & 0.02290 \\
\hline Senegal & 5595 & 6192 & 6137 & 6461 & 6881 & 7530 & 7332 & 7839 & 8026 & 8200 & 0.02274 \\
\hline Latvia & 8425 & 8799 & 8295 & 7545 & 8546 & 7792 & 7797 & 7769 & 7816 & 7973 & 0.02211 \\
\hline Papua New Guinea & 5353 & 5204 & 5741 & 5511 & 6113 & 6602 & 6841 & 7287 & 7794 & 7906 & 0.02192 \\
\hline Moldova & 8073 & 8107 & 7936 & 7705 & 8298 & 8389 & 8343 & 7365 & 7375 & 7569 & 0.02099 \\
\hline El Salvador & 7246 & 7644 & 6894 & 6913 & 6676 & 6889 & 7079 & 7206 & 7301 & 7455 & 0.02067 \\
\hline Uruguay & 6413 & 5951 & 7830 & 7991 & 6607 & 7914 & 8072 & 7076 & 7230 & 7395 & 0.02051 \\
\hline Georgia & 5225 & 6125 & 5394 & 6129 & 5647 & 6951 & 7006 & 7068 & 7017 & 7184 & 0.01992 \\
\hline
\end{tabular}




\begin{tabular}{|c|c|c|c|c|c|c|c|c|c|c|c|}
\hline Kyrgyzstan & 4002 & 4975 & 5370 & 4100 & 4963 & 5174 & 7290 & 6977 & 6832 & 7050 & 0.01955 \\
\hline Nepal & 2751 & 2767 & 3088 & 4072 & 4794 & 5420 & 6151 & 6446 & 6828 & 6984 & 0.01937 \\
\hline Botswana & 4610 & 4565 & 4624 & 4417 & 5190 & 4827 & 5028 & 6088 & 6990 & 6936 & 0.01923 \\
\hline Netherlands Antilles & 6006 & 6526 & 6456 & 6045 & 4940 & 6480 & 6470 & 6471 & 6471 & 6471 & 0.01795 \\
\hline Cyprus & 7899 & 8251 & 8420 & 8226 & 7937 & 7654 & 7244 & 6107 & 6107 & 6164 & 0.01709 \\
\hline Benin & 3856 & 4387 & 4353 & 4671 & 5040 & 5266 & 5424 & 5714 & 5668 & 5811 & 0.01612 \\
\hline Paraguay & 3949 & 4076 & 4131 & 4449 & 4930 & 5121 & 5341 & 5287 & 5422 & 5553 & 0.01540 \\
\hline Cambodia & 2972 & 3468 & 3923 & 4099 & 4137 & 4458 & 4650 & 4784 & 5211 & 5292 & 0.01468 \\
\hline Gabon & 5221 & 4762 & 5050 & 5073 & 5147 & 4742 & 4635 & 4809 & 5086 & 5242 & 0.01454 \\
\hline Uganda & 3205 & 3467 & 3865 & 3714 & 4085 & 4336 & 4486 & 4676 & 4820 & 4941 & 0.01370 \\
\hline Democratic Congo & 2656 & 2899 & 2985 & 2922 & 3040 & 3475 & 3689 & 4436 & 4858 & 4934 & 0.01368 \\
\hline Nicaragua & 4562 & 4689 & 4491 & 4490 & 4758 & 4784 & 4902 & 4686 & 4811 & 4927 & 0.01366 \\
\hline Mozambique & 2807 & 3347 & 3197 & 3432 & 3753 & 4205 & 4191 & 4538 & 4709 & 4825 & 0.01338 \\
\hline Zambia & 2714 & 1819 & 1938 & 2126 & 2224 & 2623 & 3378 & 4296 & 4767 & 4818 & 0.01336 \\
\hline Congo & 4345 & 3844 & 4029 & 4478 & 4851 & 4481 & 4121 & 4834 & 4620 & 4734 & 0.01313 \\
\hline Armenia & 4472 & 5185 & 5687 & 4549 & 4124 & 4715 & 4714 & 4552 & 4525 & 4637 & 0.01286 \\
\hline Tajikistan & 3465 & 4037 & 3732 & 3529 & 3597 & 3590 & 3570 & 4227 & 4481 & 4581 & 0.01270 \\
\hline Albania & 4098 & 4209 & 4167 & 3751 & 4075 & 4328 & 4209 & 4401 & 4354 & 4439 & 0.01231 \\
\hline Lao Republic & 1689 & 1688 & 1903 & 2440 & 2832 & 3068 & 3263 & 3436 & 4012 & 4111 & 0.01140 \\
\hline Bahamas & 2857 & 3061 & 3141 & 3180 & 3440 & 3730 & 3736 & 3851 & 3954 & 4036 & 0.01119 \\
\hline Iceland & 3232 & 3428 & 3787 & 3803 & 3656 & 3570 & 3610 & 3852 & 3893 & 3874 & 0.01074 \\
\hline Namibia & 2370 & 2448 & 2811 & 2877 & 3010 & 3162 & 3311 & 3562 & 3594 & 3679 & 0.01020 \\
\hline Mauritius & 2448 & 2553 & 2735 & 2702 & 2863 & 2980 & 3010 & 3093 & 3173 & 3239 & 0.00898 \\
\hline Madagascar & 2138 & 2372 & 2450 & 2405 & 2609 & 2731 & 2810 & 2885 & 2960 & 3022 & 0.00838 \\
\hline Guyana & 2365 & 2478 & 2392 & 2478 & 2705 & 2717 & 2728 & 2812 & 2888 & 2948 & 0.00817 \\
\hline China, Macao SAR & 1909 & 1890 & 1931 & 1972 & 2130 & 2297 & 2342 & 2497 & 2666 & 2704 & 0.00750 \\
\hline Mauritania & 1863 & 1977 & 1992 & 1968 & 2178 & 2267 & 2361 & 2433 & 2477 & 2536 & 0.00703 \\
\hline Martinique & 1908 & 2008 & 1997 & 2034 & 2159 & 2302 & 2308 & 2377 & 2439 & 2493 & 0.00691 \\
\hline Malta & 2603 & 2755 & 2592 & 2478 & 2468 & 2492 & 2432 & 2341 & 2303 & 2353 & 0.00653 \\
\hline Suriname & 1842 & 1888 & 1853 & 1887 & 1986 & 2132 & 2155 & 2226 & 2283 & 2333 & 0.00647 \\
\hline Burkina Faso & 1479 & 1672 & 1991 & 1935 & 2111 & 2187 & 2265 & 2292 & 2283 & 2333 & 0.00647 \\
\hline Haiti & 2257 & 2402 & 2485 & 2504 & 2172 & 2262 & 2135 & 2222 & 2273 & 2329 & 0.00646 \\
\hline Togo & 1212 & 1202 & 1577 & 1635 & 1774 & 2288 & 2163 & 2279 & 2225 & 2292 & 0.00635 \\
\hline Guadeloupe & 1767 & 1875 & 1854 & 1914 & 2125 & 2114 & 2120 & 2182 & 2237 & 2289 & 0.00635 \\
\hline Equatorial Guinea & 2962 & 3043 & 2863 & 2557 & 2651 & 2796 & 2232 & 2216 & 2230 & 2234 & 0.00619 \\
\hline Niger & 1438 & 1564 & 1645 & 1630 & 1763 & 1851 & 1987 & 2097 & 2138 & 2178 & 0.00604 \\
\hline Guinea & 1394 & 1496 & 1714 & 1633 & 1735 & 1851 & 1868 & 1937 & 2027 & 2075 & 0.00575 \\
\hline New Caledonia & 1692 & 1584 & 1493 & 1514 & 1647 & 1763 & 1787 & 1899 & 2019 & 2048 & 0.00568 \\
\hline Malawi & 1276 & 1349 & 1434 & 1421 & 1508 & 1546 & 1573 & 1666 & 1752 & 1792 & 0.00497 \\
\hline Mali & 1108 & 1223 & 1285 & 1279 & 1389 & 1444 & 1494 & 1534 & 1573 & 1605 & 0.00445 \\
\hline Bhutan & 676 & 733 & 800 & 1068 & 1166 & 1358 & 1365 & 1454 & 1575 & 1595 & 0.00442 \\
\hline
\end{tabular}




\begin{tabular}{|c|c|c|c|c|c|c|c|c|c|c|c|}
\hline Djibouti & 1046 & 1121 & 1180 & 1204 & 1277 & 1337 & 1342 & 1432 & 1539 & 1575 & 0.00437 \\
\hline Fiji & 943 & 933 & 1012 & 1033 & 1173 & 1260 & 1295 & 1390 & 1482 & 1506 & 0.00417 \\
\hline Barbados & 1180 & 1222 & 1206 & 1213 & 1267 & 1343 & 1328 & 1356 & 1391 & 1422 & 0.00394 \\
\hline Chad & 966 & 1085 & 1055 & 1017 & 1084 & 1126 & 1306 & 1389 & 1392 & 1418 & 0.00393 \\
\hline French Guiana & 1001 & 1061 & 1061 & 1089 & 1204 & 1253 & 1261 & 1296 & 1327 & 1356 & 0.00376 \\
\hline Rwanda & 960 & 1042 & 1091 & 1071 & 1162 & 1208 & 1246 & 1280 & 1323 & 1352 & 0.00375 \\
\hline Sierra Leone & 924 & 989 & 1042 & 1012 & 1110 & 1155 & 1184 & 1205 & 1241 & 1269 & 0.00352 \\
\hline Somalia & 922 & 1001 & 1060 & 1013 & 1102 & 1149 & 1179 & 1211 & 1242 & 1267 & 0.00351 \\
\hline Réunion & 917 & 951 & 988 & 961 & 996 & 1017 & 1056 & 1099 & 1124 & 1151 & 0.00319 \\
\hline Burundi & 762 & 830 & 880 & 841 & 916 & 967 & 1008 & 1044 & 1060 & 1081 & 0.00300 \\
\hline Maldives & 614 & 630 & 680 & 681 & 817 & 890 & 930 & 991 & 1058 & 1073 & 0.00298 \\
\hline Belize & 798 & 826 & 815 & 853 & 946 & 941 & 945 & 974 & 1000 & 1021 & 0.00283 \\
\hline French Polynesia & 593 & 581 & 599 & 611 & 681 & 736 & 757 & 807 & 861 & 873 & 0.00242 \\
\hline Liberia & 584 & 628 & 643 & 616 & 670 & 700 & 728 & 772 & 826 & 846 & 0.00235 \\
\hline Swaziland & 495 & 520 & 538 & 544 & 580 & 607 & 610 & 627 & 644 & 657 & 0.00182 \\
\hline Eritrea & 528 & 517 & 450 & 471 & 501 & 586 & 623 & 623 & 633 & 652 & 0.00181 \\
\hline Bermuda & 465 & 449 & 460 & 466 & 496 & 541 & 542 & 559 & 574 & 586 & 0.00162 \\
\hline Saint Lucia & 413 & 440 & 448 & 460 & 482 & 513 & 516 & 532 & 546 & 557 & 0.00155 \\
\hline $\begin{array}{l}\text { Central African } \\
\text { Republic }\end{array}$ & 389 & 427 & 448 & 434 & 471 & 490 & 505 & 519 & 532 & 543 & 0.00151 \\
\hline Seychelles & 381 & 410 & 423 & 435 & 460 & 482 & 483 & 496 & 509 & 519 & 0.00144 \\
\hline Grenada & 422 & 433 & 405 & 427 & 507 & 470 & 471 & 486 & 499 & 509 & 0.00141 \\
\hline Gibraltar & 425 & 422 & 431 & 472 & 478 & 459 & 466 & 495 & 499 & 502 & 0.00139 \\
\hline Timor-Leste & 233 & 190 & 209 & 257 & 278 & 320 & 534 & 509 & 444 & 448 & 0.00124 \\
\hline Antigua and Barbuda & 303 & 321 & 322 & 330 & 352 & 371 & 372 & 384 & 394 & 402 & 0.00112 \\
\hline Cayman Islands & 265 & 290 & 297 & 303 & 321 & 344 & 344 & 355 & 365 & 372 & 0.00103 \\
\hline $\begin{array}{l}\text { Saint Vincent } \\
\text { Grenadines }\end{array}$ & 256 & 272 & 271 & 278 & 295 & 306 & 308 & 317 & 325 & 332 & 0.00092 \\
\hline Guinea-Bissau & 230 & 249 & 261 & 260 & 279 & 291 & 296 & 304 & 312 & 319 & 0.00088 \\
\hline Lesotho & 238 & 256 & 268 & 256 & 277 & 289 & 296 & 304 & 312 & 318 & 0.00088 \\
\hline Montserrat & 207 & 274 & 242 & 261 & 354 & 294 & 294 & 303 & 312 & 318 & 0.00088 \\
\hline Puerto Rico & 896 & 826 & 768 & 620 & 281 & 284 & 284 & 292 & 299 & 304 & 0.00084 \\
\hline Solomon Islands & 155 & 152 & 173 & 196 & 227 & 247 & 258 & 275 & 293 & 297 & 0.00082 \\
\hline Aruba & 199 & 229 & 216 & 233 & 278 & 242 & 244 & 251 & 258 & 263 & 0.00073 \\
\hline Gambia & 181 & 196 & 206 & 205 & 221 & 231 & 236 & 243 & 249 & 254 & 0.00070 \\
\hline Tonga & 203 & 170 & 191 & 182 & 186 & 189 & 190 & 202 & 216 & 219 & 0.00061 \\
\hline Western Sahara & 148 & 159 & 168 & 171 & 182 & 191 & 193 & 198 & 203 & 207 & 0.00058 \\
\hline Saint Kitts \& Nevis & 141 & 143 & 146 & 149 & 164 & 171 & 172 & 178 & 182 & 186 & 0.00052 \\
\hline Dominica & 137 & 141 & 139 & 142 & 150 & 157 & 158 & 163 & 167 & 170 & 0.00047 \\
\hline Samoa & 105 & 93 & 97 & 107 & 115 & 124 & 128 & 137 & 146 & 148 & 0.00041 \\
\hline Vanuatu & 64 & 59 & 67 & 76 & 90 & 99 & 104 & 111 & 118 & 120 & 0.00033 \\
\hline Comoros & 74 & 84 & 88 & 87 & 94 & 98 & 101 & 104 & 106 & 108 & 0.00030 \\
\hline Cabo Verde & 72 & 80 & 82 & 81 & 87 & 91 & 93 & 95 & 98 & 100 & 0.00028 \\
\hline
\end{tabular}




\begin{tabular}{|c|c|c|c|c|c|c|c|c|c|c|c|}
\hline British Virgin Islands & 64 & 72 & 73 & 76 & 81 & 84 & 85 & 87 & 90 & 91 & 0.00025 \\
\hline $\begin{array}{l}\text { Turks \& Caicos } \\
\text { Islands }\end{array}$ & 38 & 46 & 46 & 50 & 55 & 55 & 56 & 57 & 59 & 60 & 0.00017 \\
\hline Sao Tome \& Principe & 41 & 44 & 46 & 46 & 49 & 52 & 52 & 54 & 55 & 56 & 0.00016 \\
\hline Kiribati & 27 & 24 & 27 & 31 & 35 & 38 & 40 & 42 & 45 & 46 & 0.00013 \\
\hline Falkland Islands & 31 & 33 & 35 & 35 & 37 & 41 & 41 & 42 & 44 & 45 & 0.00012 \\
\hline Palau & 35 & 29 & 33 & 31 & 32 & 32 & 31 & 34 & 36 & 36 & 0.00010 \\
\hline Cook Islands & 31 & 26 & 29 & 28 & 29 & 29 & 28 & 30 & 32 & 33 & 0.00009 \\
\hline Anguilla & 13 & 12 & 15 & 20 & 24 & 26 & 26 & 27 & 28 & 28 & 0.00008 \\
\hline $\begin{array}{l}\text { International } \\
\text { Aviation }\end{array}$ & 438250 & 452326 & 460670 & 441762 & 462439 & 478469 & 482636 & 490044 & 493592 & 502936 & \\
\hline $\begin{array}{l}\text { International } \\
\text { Shipping }\end{array}$ & 608482 & 638565 & 638428 & 612204 & 660730 & 666633 & 608735 & 618491 & 625292 & 642024 & \\
\hline World per year & 30795629 & 31959109 & 32132724 & 31821609 & 33660629 & 34725758 & 34968014 & 35672026 & 36084040 & 36061684 & \\
\hline World in 10 years & & & & & 3378 & 31222 & & & & & \\
\hline \multicolumn{12}{|c|}{$\begin{array}{l}\text { from } 1970 \text {-to-2015 but here only the data of the last ten years (2006-2015) are presented. The full data list (1970-2015) is accessible at } \\
\text { the aforementioned link. } \\
\text { **: These countries (China, United States, India, Russia, Japan and Germany) emitted in } 2015 \text { about } 60 \% \text { of the global } \mathrm{CO}_{2} \text { emission. The rest of the } \\
\text { world emitted the remaining } 40 \% \text { of } \mathrm{CO}_{2} \text {. }\end{array}$} \\
\hline
\end{tabular}

\footnotetext{
*Email: khaled.moustafa@gmail.com
} 